medRxiv preprint doi: https://doi.org/10.1101/2020.06.26.20140525; this version posted June 26, 2020. The copyright holder for this preprint

(which was not certified by peer review) is the author/funder, who has granted medRxiv a license to display the preprint in perpetuity.

All rights reserved. No reuse allowed without permission.

\title{
Hypoferremia predicts hospitalization and oxygen demand in COVID-19 patients
}

Theresa Hippchen ${ }^{1 *}$, Sandro Altamura ${ }^{2,3 *}$, Martina U. Muckenthaler ${ }^{2,3,4,5}$, Uta Merle ${ }^{1}$

*contributed equally

1 Department of Internal Medicine IV, University Hospital Heidelberg, Im Neuenheimer Feld 350, 69120 Heidelberg, Germany.

2 Pediatric Oncology, Hematology \& Immunology, University Hospital Heidelberg, Im Neuenheimer Feld 350, 69120 Heidelberg, Germany.

3 Molecular Medicine Partnership Unit, University of Heidelberg, Germany.

4 Translational Lung Research Center Heidelberg (TLRC), Member of the German Center for Lung Research, Heidelberg, Germany.

5 DZHK (German Centre for Cardiovascular Research), Partner Site Heidelberg/Mannheim, Heidelberg, Germany.

Corresponding author:

Uta Merle, Prof. Dr., Department of Internal Medicine IV, University Hospital Heidelberg

Im Neuenheimer Feld 350, 69120 Heidelberg, Tel: +49-6221-5638709, Fax: +49-6221-564116, Email:

uta.merle@med.uni-heidelberg.de

Text - Word count: 4588

Abstract - Word count: 229

Figure count: 5

Table count: 3

\section{CONFLIFT OF INTEREST DISCLOSURES}

There are no potential conflicts of interest.

\section{KEY WORDS}

COVID-19, iron, disease severity 
medRxiv preprint doi: https://doi.org/10.1101/2020.06.26.20140525; this version posted June 26, 2020. The copyright holder for this preprint

(which was not certified by peer review) is the author/funder, who has granted medRxiv a license to display the preprint in perpetuity.

All rights reserved. No reuse allowed without permission.

\section{KEY POINTS:}

1. Iron metabolism parameters are severely altered in COVID-19 patients.

2. Measurement of serum iron can help predicting the severity of COVID-19.

\section{ABSTRACT}

Background:

Iron metabolism might play a crucial role in cytokine release syndrome in COVID-19 patients. Therefore we assessed iron metabolism markers in COVID-19 patients for their ability to predict disease severity.

Methods:

COVID-19 patients referred to the Heidelberg University Hospital were retrospectively analyzed. Patients were divided into outpatients (cohort $A, n=204$ ), inpatients (cohort $B, n=81$ ), and outpatients later admitted to hospital because of health deterioration (cohort $C, n=23$ ).

Results:

Iron metabolism parameters were severely altered in patients of cohort B and C compared to cohort A. In multivariate regression analysis including age, gender, CRP and iron-related parameters only serum iron and ferritin were significantly associated with hospitalization. ROC analysis revealed an AUC for serum iron of 0.894 and an iron concentration $<6 \mu \mathrm{mol} / /$ as the best cutoff-point predicting hospitalization with a sensitivity of $94.7 \%$ and a specificity of $67.9 \%$. When stratifying inpatients in a low- and high oxygen demand group serum iron levels differed significantly between these two groups and showed a high negative correlation with the inflammatory parameters IL-6, procalcitonin, and CRP. Unexpectedly, serum iron levels poorly correlate with hepcidin.

Conclusion:

We conclude that measurement of serum iron can help predicting the severity of COVID-19. The differences in serum iron availability observed between the low and high oxygen demand group suggest that disturbed iron metabolism likely plays a causal role in the pathophysiology leading to lung injury.

\section{FUNDING}

MUM acknowledges funding from the Deutsche Forschungsgemeinschaft (SFB1036, SFB1118) and from the Federal Ministry of Education and Research (NephrESA project Nr 031L0191C). 
medRxiv preprint doi: https://doi.org/10.1101/2020.06.26.20140525; this version posted June 26, 2020. The copyright holder for this preprint (which was not certified by peer review) is the author/funder, who has granted medRxiv a license to display the preprint in perpetuity. All rights reserved. No reuse allowed without permission.

\section{INTRODUCTION}

Since iron is a critical cofactor for proteins involved in many fundamental biological processes, including DNA/RNA synthesis and ATP generation, viruses, most likely including Coronaviruses, essentially rely on iron to replicate in host cells. ${ }^{1}$ Because both, host and pathogen require iron, the host innate immune response carefully orchestrates iron metabolism to limit iron availability during times of infection. To date little is known about the interaction of the newly discovered coronavirus SARS-CoV-2 with host iron metabolism during Coronavirus disease 2019 (COVID-19).

Patients infected with SARS-CoV-2 may die due to an excessive response of their immune system, hallmarked by an abnormally high release of circulating cytokines, termed cytokine release syndrome (CRS). CRS plays a major role in the deterioration of COVID-19 patients, from pneumonia through acute respiratory distress syndrome (ARDS), cumulating in systemic inflammation and ultimately multisystem organ failure. ${ }^{2}$ This phenomenon of a plethora of cytokines wreaking havoc throughout the body is vividly referred to as "cytokine storm". Cytokines involved in the "cytokine storm" in COVID-19 patients, include IL-6, IL-1, IL-2, IL-10, and TNF- $\alpha$. However, IL-6 seems to play the most prominent role, whereby increased levels in the serum correlate with respiratory failure, ARDS, and adverse clinical outcomes. ${ }^{3}$ IL-6 is a pleiotropic cytokine involved in eliciting the acute-phase response in the liver, in B-cell proliferation and antibody production, in T-cell differentiation and cytotoxicity, and in hepcidin synthesis in the liver. ${ }^{4}$ Hepcidin is the master regulator of iron homeostasis. By degrading its target receptor ferroportin, hepcidin controls dietary iron absorption and iron release from ironrecycling macrophages. ${ }^{5}$ During states of infection or inflammation hepcidin levels increase restricting iron availability in the plasma. The resulting hypoferremia is an integral part of the host defense mechanism. Other than IL-6, several other cytokines such as IL-1, ${ }^{4} \mathrm{IL}-22,{ }^{6}$ and interferon $\alpha,{ }^{7}$ contribute to increasing hepcidin expression.

In addition to the regulation of iron metabolism via hepcidin, circulating cytokines such as IL-1 and tumor necrosis factor (TNF) increase synthesis of the iron storage protein ferritin. ${ }^{8,9}$ Consequently, more iron is retained predominantly in the reticuloendothelial system that handles most of the iron recycled from damaged red blood cells. The resulting hypoferremia disturbs erythropoiesis and iron uptake in most organs. ${ }^{10,11}$

As the control of iron metabolism is crucial during infections in general and because several cytokines involved in the "cytokine storm" in COVID-19 are strong regulators of iron metabolism, understanding of iron homeostasis in COVID-19 is likely to be a relevant piece in the puzzle of COVID-19 disease. In this study, we noted that severe COVID-19 cases not only show higher levels of inflammatory markers than mild cases, but also that iron metabolism parameters greatly differed depending on disease severity.

Therefore we focused our attention on iron-related parameters in COVID-19 patients and showed that (1) severely ill COVID-19 patients show marked hypoferremia, (2) the level of hypoferremia predicts disease severity (reflected in hospitalization requirement), (3) hypoferremia only partially correlates with hepcidin and inflammatory markers like C-reactive protein (CRP) and IL-6, and (4) immunomodulatory therapeutic agents (e.g. IL-1R blockade, IL-6R blockade and immunoglobulins) $)^{3,12}$ show a rapid and strong effect on hypoferremia in COVID-19 patients. 
medRxiv preprint doi: https://doi.org/10.1101/2020.06.26.20140525; this version posted June 26, 2020. The copyright holder for this preprint (which was not certified by peer review) is the author/funder, who has granted medRxiv a license to display the preprint in perpetuity. All rights reserved. No reuse allowed without permission.

\section{RESULTS}

\section{Baseline characteristics of patient cohorts}

Our outpatient cohort (cohort A) consists of 204 outpatients who remained home throughout the entire course of the disease. 23 patients were initially followed as outpatients but later had to be admitted to the hospital because of clinical worsening. These patients are summarized as cohort $\mathrm{C}$. In addition, we analyzed an inpatient cohort (cohort B) consisting of 81 patients. Table 1 shows the baseline characteristics and treatments of all three cohorts. In cohort B, 48 patients $(59.3 \%)$ had low oxygen demand (no or low-flow oxygen requirement) while 33 patients $(40.7 \%)$ showed high oxygen demand (high flow oxygen or invasive ventilation). 14 (17.3\%) inpatients of cohort $B$ died, while all patients in cohort $A$ and $C$ survived. Table 2 depicts lab values of patients in all three cohorts. Some of the outpatients of cohort $A$ and $C$ were followed on more than one outpatient visit and data of all timepoints are included in laboratory analyses shown in table 2. This explains the results of 415 visits in 204 patients of cohort $A$ and 48 visits in 23 patients of cohort $C$. The inpatient cohort B differs significantly from Cohort $A$ in all laboratory parameters analyzed.

\section{Serum iron levels predict hospitalization in COVID-19 patients}

COVID-19 patients show strongly elevated inflammatory markers, such as CRP and IL-6, confirming results of previous studies. ${ }^{13}$ In addition, the iron-related parameters analyzed (ferritin, serum iron, TfSat, transferrin and hepcidin) severely deviated from normal in all cohorts. When comparing our cohorts, outpatients of cohort A showed less severe alterations compared to those outpatients that had to be admitted to the hospital because of clinical worsening (cohort $C$ ) (table 2). Similarly, iron markers were altered more severely in the inpatient cohort B compared to outpatients in cohort $A$ (table 2). The differences in iron-related parameters in part were gender-specific, with females of cohort A deviating less from the normal range for serum iron, transferrin and ferritin compared to males, while in cohort $B$ and $C$ only ferritin was significantly higher in males (figure 1).

Utilizing this unique cohort set up of in- and outpatients, we performed univariate logistic regression analysis for age, gender, CRP, and iron markers with respect to hospitalization requirement of COVID19 patients reflecting upon disease severity (table 3). Interestingly, in univariate analysis, all iron metabolism parameters were significantly associated with admission status. In multivariate regression analysis including age, gender, CRP and iron markers only serum iron and ferritin were significantly associated with hospitalization, whereby doubling of serum iron was associated with a 6.7-fold lower odd of hospitalization (adjusted OR per log2 increase in serum iron: $0.15,95 \% \mathrm{Cl} 0.09-0.26, \mathrm{P}<0.001$ ) (table 3).

To determine the best discriminating cut-off predicting hospitalization we performed ROC-analysis (figure $2 \mathrm{~A}$ and $2 \mathrm{~B}$ ). An iron concentration $<6 \mu \mathrm{mol} / / \mathrm{l}$ was identified as the best cutoff-point predicting hospitalization. The sensitivity of iron levels at this value was $94.7 \%$ with a specificity of $67.9 \%$. The predictive power of iron, expressed as area under the ROC curve (AUC), was 0.894 , with a $95 \%$ confidence interval of $0.858-0.931$. The ROC curve AUCs for TfSat, transferrin, ferritin, and CRP 
medRxiv preprint doi: https://doi.org/10.1101/2020.06.26.20140525; this version posted June 26, 2020. The copyright holder for this preprint (which was not certified by peer review) is the author/funder, who has granted medRxiv a license to display the preprint in perpetuity. All rights reserved. No reuse allowed without permission.

were lower compared to iron (0.863 (Cl 0.824-0.903), 0.735 (Cl 0.676-0.795), 0.725 (Cl 0.667-0.784), and 0.838 ( $\mathrm{Cl} 0.790-0.886)$, respectively).

Outpatients that were monitored in the days before being admitted to hospital because of increasing disease severity showed a decline of serum iron in the days before admission (figure $2 \mathrm{C}$ ). However, cohort $C(n=23)$ is small and patients were not monitored at each individual time point; thus, this observation did not reach statistical significance.

Of note, compared to the widely used CRP value, serum iron was predictive in multivariate regression analysis while CRP was not and in ROC analysis the AUC was better for iron than CRP in discriminating in- and outpatients. In conclusion, iron levels are highly predictive for disease progression and hospitalization of COVID19 patients.

\section{Course of iron-related biomarkers and markers of inflammation during hospitalization}

The dynamics of blood parameter alterations may provide interesting insights into COVID-19 disease pathology. Therefore, we focused our analyses on the inpatient cohort and analyzed blood parameters on a daily basis starting from the time of admission (d0) until day 6 (d6). This inpatient cohort was further stratified in a low- $(n=48)$ and a high oxygen demand group $(n=33)$. We investigated whether iron (serum iron, transferrin, hemoglobin) and inflammatory (serum CRP and IL-6) markers differ between patients with low versus high oxygen demand (figure 3). At the day of admission serum iron levels were low in both groups, but increased over the course of the disease in the low-oxygen demand group. By contrast, serum iron levels remained low in the high oxygen demand group. As a result, iron levels differed significantly depending on the oxygen requirement of patients from day three after admission TfSat, an additional indicator of systemic iron availability follows a similar pattern even though the difference does not reach statistical significance at any time point. Severe iron deficiency frequently causes anemia. Consistently, hemoglobin levels are decreased in high oxygen demand patients, suggesting that iron restriction affects the oxygen transport capacity of hemoglobin likely contributing to high oxygen requirement. Additionally, transferrin levels are significantly decreased at the time of hospitalization, which persists over time.

The cytokine IL-6 activates the expression of the peptide hormone hepcidin that causes hypoferremia by blocking iron export from macrophages. Consistently, COVID-19 patients show significantly increased IL-6 and hepcidin levels and a significant correlation of these two parameters. Unexpectedly, hepcidin levels only poorly inversely correlated with serum iron levels. In addition, hepcidin was unable to discriminate between the low and high oxygen demand group, despite the fact that the pro-inflammatory cytokine IL6 and the inflammatory marker CRP are elevated to a higher degree in patients with high oxygen demand compared to those with low oxygen demand. Ferritin levels are highly variable and therefore do not significantly differentiate patients with high and low oxygen demand. Overall, serum iron levels show a high negative correlation with the inflammatory parameters IL-6 and PCT from d0 to d6, while correlation with CRP increases over the time course (figure 4). As expected, iron positively correlates with transferrin saturation and hemoglobin.

We next asked whether hypoferremia correlates with markers for organ damage. Interestingly, low serum iron levels inversely correlate with the cardiac injury marker Troponin-T, while correlations for kidney, liver damage or coagulation were not observed. In addition, transferrin shows a significant 
medRxiv preprint doi: https://doi.org/10.1101/2020.06.26.20140525; this version posted June 26, 2020. The copyright holder for this preprint (which was not certified by peer review) is the author/funder, who has granted medRxiv a license to display the preprint in perpetuity. All rights reserved. No reuse allowed without permission.

inverse correlation with CRP, IL-6, procalcitonin, ferritin, and D-dimers as well as with heart damage parameters Troponin-T and NT-pro-BNP. IL-6 has a similar correlation pattern like transferrin but in addition also negatively correlates with the iron metabolism parameters analyzed.

\section{Immunomodulatory therapies increase iron availability}

Current management of COVID-19 is mainly supportive and approved treatments based on scientific evidence are not available. Main causes of death include ARDS and cytokine storm syndrome therefore therapy with intravenous immunoglobulins (IVIG) or with agents blocking cytokines, like IL-6 receptor antagonist tocilizumab and the IL-1 receptor antagonist anakinra may be efficient. ${ }^{12,14}$

All three treatments have a high anti-inflammatory potential, which allowed us to study the influence of these therapies on iron biomarkers.

In figure 5 the course of iron metabolism parameters before immunomodulatory treatment (defined as day 0 ) and in the 6 days after treatment is shown. We observed strong effects on serum iron levels and transferrin saturation following therapy with anakinra, tocilizumab and immunoglobulins. When comparing the mean of serum iron levels and transferrin saturation of all patients per treatment group at d1 and d0 these increased 1.8- and 2.1-fold, respectively, after anakinra treatment, 2.0- and 2.2fold, respectively for tocilizumab treatment, and 2.3- and 2.5-fold, respectively, after immunoglobulin treatment.

\section{DISCUSSION}

SARS-CoV-2 infection leads to a broad spectrum of clinical outcomes, spanning from asymptomatic to lethal. ${ }^{15}$ Most of the patients show only moderate symptoms such as weakness, sore throat and fever but in some, the disease progresses to ARDS which in extreme cases can be fatal. Therefore a clinical marker predicting outcome for timely intervention is in high demand. Most studies so far focused on immunologic characteristics as potential markers for monitoring disease severity in COVID-19 patients. ${ }^{16}$

Although iron metabolism plays a central role in the outcome of infections, knowledge about the dynamics of players controlling iron homeostasis in COVID-19 patients is scarce. Our study reveals the predictive value of iron-related markers in patients with confirmed COVID-19 disease. We focus on these parameters as early indicators for disease progression and guidance for therapy decisions in severely affected patients.

We analyzed diagnostic data from our unique patient cohort that is separated into (i) patients with less severe disease taken care of by clinical staff in an outpatient setting (cohort A), (ii) patients initially taken care of in the outpatient setting, but that later deteriorated and had to be admitted to the hospital (cohort C) and (iii) severely ill inpatients (Cohort B). This unique cohort allowed us to determine biomarkers that predict for disease severity reflected by the need for hospitalization and oxygen requirement.

Iron metabolism parameters are disturbed in outpatients and inpatients. Compared to mildly affected patients that remained at an outpatient level, the inpatient cohort shows a significantly more pronounced derangement of iron metabolism parameters. Of note, we observed a gender difference 
medRxiv preprint doi: https://doi.org/10.1101/2020.06.26.20140525; this version posted June 26, 2020. The copyright holder for this preprint (which was not certified by peer review) is the author/funder, who has granted medRxiv a license to display the preprint in perpetuity. All rights reserved. No reuse allowed without permission.

for ferritin in all three cohorts and for serum iron as well as transferrin levels in cohort A, with males being more affected than females. As for COVID-19 a gender difference in disease severity is well recognized, we speculate that lower serum iron levels as well as higher ferritin levels in male patients may be linked with more severe COVID-19 disease in male patients.

In multivariate analysis only serum iron levels and ferritin are significantly predicting disease severity, while CRP, age, gender, as well as transferrin and its saturation are not. Based on a multiple regression analysis model, the odds ratio for hospital admission was 6.7-fold lower per two-fold increase in serum iron. This shows the highly predictive value of serum iron but further hints to a high relevance of altered iron metabolism in the pathogenesis of COVID-19 in the second disease phase typically occurring after the 6th day of disease onset.

Additionally, ROC analysis shows that serum iron levels discriminate outpatients from inpatients, accurately predicting their need for hospitalization. For predicting disease severity reflected in admission status ROC analysis reveals a higher AUC for serum iron (AUC 0.894 with a 95\% confidence interval of $0.858-0.931$ ) compared to CRP and ferritin levels, that are previously reported COVID-19 severity markers. ${ }^{17}$ An iron concentration $<6 \mu \mathrm{mol} / /$ was identified as the best cutoff-point predicting hospitalization. The sensitivity of iron levels at this value is $94.7 \%$ with an acceptable specificity for a screening marker of $67.9 \%$. In summary, we suggest to assess serum iron parameters in outpatients regularly in order to detect deterioration at an early time point.

The analysis of plasma parameters in 81 patients with COVID-19 hospitalized in the University Hospital Heidelberg provides interesting insights into COVID-19 disease pathology. In this 'in-patient' cohort, we analyzed blood parameters on a daily basis starting from the time of admission (d0) until day 6 (d6). Consistent with previous reports, we observed a pronounced 'inflammatory status' of COVID-19 patients. Together with inflammation, the most pronounced changes are observed in ironrelated parameters. COVID-19 patients show severe hypoferremia, indicated by extremely low serum iron levels and transferrin saturation. Reduced iron availability mildly reduces hemoglobin levels suggesting that this may contribute to the poor oxygenation in severely affected patients. We expect that several mechanisms contribute to the generation of hypoferremia in COVID-19 patients. One major mechanism is the increase of the iron-regulated hormone hepcidin during the acute phase response in the inpatient cohort. In response to inflammation, hepcidin transcription is activated by the cytokine IL-6 via the JAK/STAT signaling pathway. Consistently, during the 6-day time course hepcidin and IL-6 correlate, whereby both initially increase and subsequently decline. Hepcidin triggers degradation of the iron exporter ferroportin thus blocking iron release to the blood stream. Therefore, high amounts of iron derived from the recycling process of senescent red blood cells are retained in macrophages. Both macrophage iron accumulation and inflammation will contribute to the rise in levels of the iron-storage protein ferritin, a marker consistently observed in our in-patient cohort. Iron retention in macrophages due to high hepcidin levels may at least in part explain the severity of hypoferremia in COVID-19 patients. Unexpectedly, Spearman's correlation analysis, which confirms strong direct correlations between serum iron levels and transferrin saturation and inverse correlations between hepcidin and the inflammatory markers IL-6, PCT and CRP (figure 4), failed to reveal a correlation between serum iron and hepcidin levels. We suspect that the transcriptional repression of the iron exporter ferroportin via pro-inflammatory cytokines may be a driving force causing 
medRxiv preprint doi: https://doi.org/10.1101/2020.06.26.20140525; this version posted June 26, 2020. The copyright holder for this preprint (which was not certified by peer review) is the author/funder, who has granted medRxiv a license to display the preprint in perpetuity. All rights reserved. No reuse allowed without permission.

hypoferremia in COVID-19 patients. $^{18,19}$ In addition, the elevation of hepcidin levels in COVID-19 patients may be inadequate in the context of the extreme inflammation. It is possible that the hypoxic state in COVID-19 patients triggers erythropoietin-dependent expression of the blood hormone erythroferrone in erythroid precursor cells, which in turn represses hepcidin in hepatocytes explaining the poor correlation between hepcidin levels and the degree of hypoferremia in these patients. Thus, the cytokine storm reported in COVID-19 patients may cause hypoferremia by at least three mechanisms, hepcidin-mediated ferroportin degradation, transcriptional downregulation of ferroportin, and elevated iron retention due to high ferritin levels. Of note, COVID-19 patients also show strongly decreased transferrin levels. While literature links inflammation with decreased serum transferrin, ${ }^{20,21}$ the molecular mechanism and biological meaning of this phenomenon are not clear.

As outlined above, high ferritin levels may in part be explained by iron retention in macrophages. We have previously shown that macrophages exposed to heme and/or iron released during hemolysis undergo a phenotypic change that is hallmarked by a pro-inflammatory state. ${ }^{22}$ Heme release from red blood cells is frequently observed in conditions of sepsis. COVID-19 patients show elevated LDH levels, a marker for hemolysis. We therefore propose that COVID-19 patients with severe hypoferremia likely display a high degree of iron accumulation in macrophages that, together with hemolysis may contribute to the severe inflammation observed in these patients.

Another important finding of this study is that iron levels negatively correlate with the myocardial damage marker Troponin-T, suggesting that reduced iron availability could be a co-factor for cardiac stress. The heart is particularly rich in mitochondria that rely on a large amount of iron to produce energy via oxidative phosphorylation. Consistently, iron deficiency has been widely reported as a possible comorbidity for cardiac injury. ${ }^{23,24}$

Similar to hypoferremia, transferrin and IL6 display a strong correlation with inflammatory markers (CRP, PCR and Leukocyte number), markers of tissue-damage (LDH) and cardiac injury (Troponin-T and NT-pro-BNP). However, in addition, these two markers correlate with the glomerular filtration rate and serum urea levels, even though these parameters do not reach pathological level (table 3).

Under low oxygen conditions, erythropoietin stimulates erythropoiesis, a process that requires high amounts of iron. ${ }^{5}$ We next questioned whether the immense reduction in systemic iron availability in COVID-19 patients may be involved in the worsening of ARDS. Using a retrospective approach, we divided cohort B into two subgroups, those with high and those with low oxygen demand. We observed that serum iron levels are lower in patients with high oxygen demand already at the time of admission to the hospital, a difference that increases during the time course and becomes significant three days later. A similar tendency is observed for transferrin saturation at most time points analyzed. Taken together, our data suggest that reduced iron availability is associated with and might even contribute to the progression of ARDS in COVID-19 patients. Additional studies are required to address how iron availability contributes to ARDS.

As hypoferremia is correlated with CRP- and IL-6 -levels we wanted to understand the influence of immunomodulatory therapies on iron levels. Of interest, all three analyzed anti-inflammatory treatments showed a rapid and profound influence on serum iron levels already one day after therapy. The fact that serum iron levels increased after all three anti-inflammatory treatments is in line with our hypothesis that inflammation is the major driver of hypoferremia. Interestingly, the influence of 
medRxiv preprint doi: https://doi.org/10.1101/2020.06.26.20140525; this version posted June 26, 2020. The copyright holder for this preprint (which was not certified by peer review) is the author/funder, who has granted medRxiv a license to display the preprint in perpetuity. All rights reserved. No reuse allowed without permission.

anakinra and tocilizumab on ferritin levels was only mild. This may be explained by immune dysregulation in severe COVID-19 patients that has previously been shown to be only partially normalized by tocilizumab. ${ }^{25}$ The fact that in our studies hypoferremia reacts differently than CRP- and IL-6 levels shows that immune dysregulation in COVID-19 is complex and has to be further analyzed in future studies.

In summary we show that measurement of serum iron levels can help in predicting the severity of COVID-19 disease. We propose that both, hypoferremia as well as the expected iron accumulation in macrophages may play a causal role in the pathophysiology of this disease leading to lung injury.

\section{PATIENTS AND METHODS}

\section{Patient selection}

All patients with laboratory-confirmed SARS-CoV-2 infection with an age of 18 years or older that were followed as an out- or inpatient at the University hospital of Heidelberg between March 1st and April 23rd, 2020 were considered for inclusion. Data analysis was approved (number S-148/2020) by the Ethics Committee of the Medical Faculty Heidelberg.

Diagnosis of SARS-CoV-2 infection was based on a positive reverse-transcriptase quantitative polymerase chain reaction (RT-qPCR) to detect the viral genome from individual throat swabs or airway surface liquid.

The outpatient cohort consisted of patients who were visited at regular intervals by medically trained staff at their homes, because they reported relevant symptoms like dyspnea or continuously high fever. The outpatients could either stay at home for the entire course of the disease (cohort A) or were admitted to our hospital because of relevant deterioration (cohort $\mathrm{C}$ ).

All patients that were admitted to the Internal Medicine department of the University hospital Heidelberg due to SARS-CoV-2 infection were considered for inclusion into the in-patient cohort (cohort B). Additional inclusion criteria for the inpatient cohort were severe symptoms (like severe dyspnea or neurological symptoms) and/or a severe or critical course of COVID-19 at the admission time point. Severe COVID-19 was defined as patients showing one or more of the following characteristics at admission to hospital: respiratory rate $\geq 30 / \mathrm{min}$, blood oxygen saturation $\leq 93 \%$, ratio of partial pressure of oxygen in arterial blood over the fraction of inspired oxygen $<300 \mathrm{mmHg}$. Patients that had been primarily treated in other hospitals and were secondarily transferred after an external treatment period of $>48 \mathrm{~h}$ were not included in the study cohort. In addition, patients that were only hospitalized for quarantine or psychological reasons were also excluded from the analysis. Based on these criteria 81 inpatients were included for further analysis and 12 patients were excluded.

For all patients' baseline characteristics, treatments, oxygen requirement, laboratory values, and outcome measures were obtained. Inpatients were stratified in a low and high oxygen demand group. All patients requiring High-Flow-Nasal-Oxygen (HFNO) or invasive ventilation in order to reach a blood oxygen saturation $>93 \%$ were stratified in the high-oxygen demand group, and all remaining patient in the low-oxygen demand group. Furthermore, hepcidin levels were measured using a commercially available ELISA assay according to the manufacturer's instructions (DRG Diagnostics). 
medRxiv preprint doi: https://doi.org/10.1101/2020.06.26.20140525; this version posted June 26, 2020. The copyright holder for this preprint (which was not certified by peer review) is the author/funder, who has granted medRxiv a license to display the preprint in perpetuity. All rights reserved. No reuse allowed without permission.

To study the effects of certain highly immunomodulatory therapeutic agents on iron metabolism we analyzed defined cohorts of patients before and after treatment with anakinra, tocilizumab, and intravenous immunoglobulins (IVIG).

The study was approved by the local ethics committee in Heidelberg (ethics approval number S148/2020) and was conducted in accordance with the Declaration of Helsinki.

\section{Statistical analysis}

Data in tables are presented as median with interquartile range (IQR) and as numbers (with percentages) in case of categorical data. For comparison between variables, the Mann-Whitney U-test or Wilcoxon's test, chi-squared or Fisher's exact test were used as appropriate. In case of multiple comparisons, the p-value has been corrected with the Holm method. Spearman's correlation was used to determine correlation of laboratory values. Since CRP levels and iron parameters showed a leftskewed distribution, data was log2 transformed for further analysis. A univariate logistic regression analysis was chosen as the screening method to assess the relationships between putative predictive parameters and the severity of COVID-19, that was defined either by the status of the patients (inversus outpatient) and for the inpatients by the oxygen demand (low versus high oxygen demand). The predictor variables identified as significant by the univariate logistic analysis were then entered into a multiple logistic regression model to establish which of them could most accurately predict COVID-19 severity including age, gender, and CRP as confounders. Model calibration was evaluated by using the Hosmer-Lemeshow goodness-of-fit test. ${ }^{26}$ The odds ratios (ORs) and their 95\% confidence intervals (Cls) for each of the variables were then generated to clarify the respective association of each of the risk factors with the COVID-19 severity. In addition, receiver operating characteristic (ROC) curve analysis with calculation of the area under the curve (AUC) was performed. Data collection and analyses were performed using SPSS 21 (IBM Corp. Armonk, NY, USA) or with GraphPad prism 8 (GraphPad Software, San Diego, CA, USA). For all tests, a p-value $<0.05$ was considered to be statistically significant.

\section{AUTHORSHIP CONTRIBUTIONS}

The rationale was drafted by UM. Patients were treated by UM and TH. Data acquisition was done by TH and UM. Data analyses, interpretation, and figure design were carried out by SA, UM, MUM, and $\mathrm{TH}$. The manuscript was written by UM, MUM, SA, and TH. All authors revised and approved the manuscript.

\section{REFERENCES}

1. Drakesmith H, Prentice A. Viral infection and iron metabolism. Nat Rev Microbiol 2008; 6(7): 541-552.

2. Xu Z, Shi L, Wang Y, et al. Pathological findings of COVID-19 associated with acute respiratory distress syndrome. Lancet Respir Med 2020; 8(4): 420-422.

3. Ye Q, Wang B, Mao J. The pathogenesis and treatment of the 'Cytokine Storm' in COVID-19. J Infect 2020.

4. Lee $\mathrm{P}$, Peng $\mathrm{H}$, Gelbart T, Wang L, Beutler E. Regulation of hepcidin transcription by interleukin-1 and interleukin-6. Proc Natl Acad Sci U S A 2005; 102(6): 1906-1910. 
medRxiv preprint doi: https://doi.org/10.1101/2020.06.26.20140525; this version posted June 26, 2020. The copyright holder for this preprint (which was not certified by peer review) is the author/funder, who has granted medRxiv a license to display the preprint in perpetuity. All rights reserved. No reuse allowed without permission.

5. Muckenthaler MU, Rivella S, Hentze MW, Galy B. A Red Carpet for Iron Metabolism. Cell 2017; 168(3): 344-361.

6. Armitage $A E$, Eddowes $L A$, Gileadi $U$, et al. Hepcidin regulation by innate immune and infectious stimuli. Blood 2011; 118(15): 4129-4139.

7. Ryan JD, Altamura S, Devitt E, et al. Pegylated interferon-alpha induced hypoferremia is associated with the immediate response to treatment in hepatitis C. Hepatology 2012; 56(2): 492500.

8. Torti SV, Kwak EL, Miller SC, et al. The molecular cloning and characterization of murine ferritin heavy chain, a tumor necrosis factor-inducible gene. J Biol Chem 1988; 263(25): 12638-12644.

9. Wei Y, Miller SC, Tsuji Y, Torti SV, Torti FM. Interleukin 1 induces ferritin heavy chain in human muscle cells. Biochem Biophys Res Commun 1990; 169(1): 289-296.

10. Smirnov IM, Bailey K, Flowers CH, Garrigues NW, Wesselius LJ. Effects of TNF-alpha and IL1 beta on iron metabolism by A549 cells and influence on cytotoxicity. Am J Physiol 1999; 277(2): L257-263.

11. Tsuji Y, Miller LL, Miller SC, Torti SV, Torti FM. Tumor necrosis factor-alpha and interleukin 1alpha regulate transferrin receptor in human diploid fibroblasts. Relationship to the induction of ferritin heavy chain. J Biol Chem 1991; 266(11): 7257-7261.

12. $\mathrm{Xu} \mathrm{X}$, Han M, Li T, et al. Effective treatment of severe COVID-19 patients with tocilizumab. Proc Natl Acad Sci U S A 2020.

13. Chen W, Zheng KI, Liu S, Yan Z, Xu C, Qiao Z. Plasma CRP level is positively associated with the severity of COVID-19. Ann Clin Microbiol Antimicrob 2020; 19(1): 18.

14. Aouba A, Baldolli A, Geffray L, et al. Targeting the inflammatory cascade with anakinra in moderate to severe COVID-19 pneumonia: case series. Ann Rheum Dis 2020.

15. Velavan TP, Meyer CG. Mild versus severe COVID-19: Laboratory markers. Int J Infect Dis 2020; 95: 304-307.

16. Liu F, Li L, Xu M, et al. Prognostic value of interleukin-6, C-reactive protein, and procalcitonin in patients with COVID-19. J Clin Virol 2020; 127: 104370.

17. Zhou F, Yu T, Du R, et al. Clinical course and risk factors for mortality of adult in patients with COVID-19 in Wuhan, China: a retrospective cohort study. Lancet 2020; 395(10229): 1054-1062.

18. Guida C, Altamura S, Klein FA, et al. A novel inflammatory pathway mediating rapid hepcidinindependent hypoferremia. Blood 2015; 125(14): 2265-2275.

19. Liu XB, Nguyen NB, Marquess KD, Yang F, Haile DJ. Regulation of hepcidin and ferroportin expression by lipopolysaccharide in splenic macrophages. Blood Cells Mol Dis 2005; 35(1): 47-56.

20. Matusiewicz M, Neubauer K, Lewandowska P, Gamian A, Krzystek-Korpacka M. Reduced Transferrin Levels in Active Inflammatory Bowel Disease. Biomed Res Int 2017; 2017: 9541370.

21. Ritchie RF, Palomaki GE, Neveux LM, Navolotskaia O, Ledue TB, Craig WY. Reference distributions for the negative acute-phase serum proteins, albumin, transferrin and transthyretin: a practical, simple and clinically relevant approach in a large cohort. J Clin Lab Anal 1999; 13(6): 273279.

22. Vinchi F, Costa da Silva $M$, Ingoglia $G$, et al. Hemopexin therapy reverts heme-induced proinflammatory phenotypic switching of macrophages in a mouse model of sickle cell disease. Blood 2016; 127(4): 473-486.

23. Fitzsimons $S$, Doughty RN. Iron deficiency in patients with heart failure. Eur Heart J Cardiovasc Pharmacother 2015; 1(1): 58-64.

24. Huang $\mathrm{CH}$, Chang $\mathrm{CC}$, Kuo $\mathrm{CL}$, et al. Serum iron concentration, but not hemoglobin, correlates with TIMI risk score and 6-month left ventricular performance after primary angioplasty for acute myocardial infarction. PLoS One 2014; 9(8): e104495.

25. Giamarellos-Bourboulis EJ, Netea MG, Rovina N, et al. Complex Immune Dysregulation in COVID-19 Patients with Severe Respiratory Failure. Cell Host Microbe 2020.

26. Lemeshow S, Hosmer DW, Jr. A review of goodness of fit statistics for use in the development of logistic regression models. Am J Epidemiol 1982; 115(1): 92-106. 
medRxiv preprint doi: https://doi.org/10.1101/2020.06.26.20140525; this version posted June 26, 2020. The copyright holder for this preprint (which was not certified by peer review) is the author/funder, who has granted medRxiv a license to display the preprint in perpetuity.

\section{FIGURE LEGENDS}

\section{Figure 1}

Boxplots representing iron metabolism parameters in female (in red) and male (in blue) patients of cohort A, B and C. Cohort A: 204 outpatients (with 1 to 8 visits per patient, in summary 415 visits); Cohort B: 81 patients with lab values at day of admission; Cohort C: 23 outpatients with clinical worsening and subsequent hospital admission in the course of the disease (with visits up to 9 days before hospital admission and 1 to 6 visits per patient, in summary 48 visits). Figure A: serum iron; B: serum transferrin; C: transferrin saturation; $D$ : serum ferritin.

Data are presented as boxplot (median \pm interquartile range). Statistical significant distribution of parameters was tested with the Mann-Whitney $U$ test.

\section{Figure 2}

$A, R O C$ curve for cohort $A$ and $B$ for predicting hospitalization for iron, transferrin and TfSat with AUCs of $0.894,0.735$, and 0.863 , respectively (and confidence intervals of 0.858-0.931, 0.676-0.795, and 0.824-0.903, respectively).

$B, R O C$ curve for cohort A and B for predicting hospitalization for ferritin and CRP with AUCs of 0.725 (Cl 0.667-0.784), and 0.838 ( $\mathrm{Cl} 0.790-0.886)$, respectively.

C, Course of iron pre-hospitalization for cohort C. Data are presented as boxplot (median \pm interquartile range).

\section{Figure 3}

Course of iron and inflammatory parameters in inpatients during the disease course. Serum iron, transferrin, transferrin saturation, hepcidin, hemoglobin ( $\mathrm{Hgb}$ ), ferritin, IL-6 and CRP have been measured at the time of admission (d0) and for 6 following days (d1-d6).

Box and whiskers plot represent median with $25^{\text {th }}$ and $75^{\text {th }}$ percentiles (boxes) together with $10^{\text {th }}$ and $90^{\text {th }}$ percentiles (whiskers). Statistical analysis was performed with the Mann-Whitney $U$ test and the $p-$ value has been corrected for multiple comparisons with the Holm method.

ns: not significant; ${ }^{*} p<0.05 ;{ }^{* *} p<0.01 ;{ }^{* * *} p<0.001 ;{ }^{* * *} p<0.0001$

\section{Figure 4}

Heatmap of the Spearman's $r$ correlation analysis of iron, transferrin and IL- 6 with the parameters indicated. White boxes indicate a lack of correlation $(p>0.05)$ while in red and blue are reported statistically significant direct and indirect correlations, respectively. The intensity of the color indicates the $-\log 10$ (pvalue).

\section{Figure 5}

Iron metabolism parameters and CRP before (day0) and in the days after administration of immunomodulatory medication. Displayed are the courses of serum iron, TfSat, ferritin, CRP, and IL-6 for each individual patient under the three different therapies: Anakinra ( $n=6$ patients); Tocilizumab 
medRxiv preprint doi: https://doi.org/10.1101/2020.06.26.20140525; this version posted June 26, 2020. The copyright holder for this preprint (which was not certified by peer review) is the author/funder, who has granted medRxiv a license to display the preprint in perpetuity.

All rights reserved. No reuse allowed without permission.

( $\mathrm{n}=4$ patients); intravenous immunoglobulins (IVIG) ( $\mathrm{n}=6$ patients). Data are represented as mean \pm s.e.m. 
medRxiv preprint doi: https://doi.org/10.1101/2020.06.26.20140525; this version posted June 26, 2020. The copyright holder for this preprint (which was not certified by peer review) is the author/funder, who has granted medRxiv a license to display the preprint in perpetuity.

All rights reserved. No reuse allowed without permission.

\section{TABLES}

Table 1 Baseline characteristics of study population. Results are presented as numbers (with \%) or median (with interquartile range)

\begin{tabular}{|c|c|c|c|c|c|}
\hline & $\begin{array}{c}\text { Cohort A } \\
(n=204)\end{array}$ & $\begin{array}{c}\text { Cohort B } \\
(n=81)\end{array}$ & p-value* & $\begin{array}{c}\text { Cohort C } \\
(n=23)\end{array}$ & p-value ${ }^{\star *}$ \\
\hline Age (years) & $51(36-62)$ & $64(54-75)$ & $<0.001$ & $58(52-68)$ & 0.029 \\
\hline Gender (male) & $67(32.8 \%)$ & $53(65.4 \%)$ & $<0.001$ & $15(65.2 \%)$ & 0.008 \\
\hline Event of death & 0 & $14(17.3 \%)$ & & 0 & \\
\hline No Oxygen & $204(100 \%)$ & $8(19.5 \%)$ & & $23(100 \%)$ & \\
\hline Lowflow therapy & & $40(49.4 \%)$ & & & \\
\hline Highflow therapy & & $12(14.8 \%)$ & & 0 & \\
\hline Invasive ventilation & & $21(25.9 \%)$ & & & \\
\hline \multicolumn{6}{|l|}{ ARDS } \\
\hline -mild & 0 & $5(6.2 \%)$ & & 0 & \\
\hline -moderate & 0 & $15(18.5 \%)$ & & 0 & \\
\hline -severe & 0 & $13(16.0 \%)$ & & 0 & \\
\hline \multicolumn{6}{|l|}{ Treatments } \\
\hline -no treatment & $204(100 \%)$ & 0 & & $23(100 \%)$ & \\
\hline -antibiotic/antifungal treatment & & $81(100 \%)$ & & & \\
\hline -maraviroc & & $48(59.3 \%)$ & & & \\
\hline -hydroxychloroquine & & $52(65 \%)$ & & & \\
\hline -anakinra & & $6(7.4 \%)$ & & & \\
\hline -tocilizumab & & $4(4.9 \%)$ & & & \\
\hline -immunoglobulines (IVIG) & & $6(7.4 \%)$ & & & \\
\hline -plasmapheresis & & $3(3.7 \%)$ & & & \\
\hline -cytosorb $®$ & & $2(2.5 \%)$ & & & \\
\hline -convalescent serum & & $2(2.5 \%)$ & & & \\
\hline
\end{tabular}

${ }^{*}$ Comparison of $p$-values between cohort $A$ and $B$

${ }^{* *}$ Comparison of $p$-values between cohort $A$ and $C$ 
medRxiv preprint doi: https://doi.org/10.1101/2020.06.26.20140525; this version posted June 26, 2020. The copyright holder for this preprint (which was not certified by peer review) is the author/funder, who has granted medRxiv a license to display the preprint in perpetuity. All rights reserved. No reuse allowed without permission.

Table 2 Laboratory findings of the study cohorts. Results are presented as median (with interquartile range)

\begin{tabular}{|c|c|c|c|c|c|c|}
\hline & $\begin{array}{c}\text { normal } \\
\text { range }\end{array}$ & $\begin{array}{c}\text { Cohort A } \\
(n=204)\end{array}$ & $\begin{array}{c}\text { Cohort B } \\
(n=81)\end{array}$ & p-value* & $\begin{array}{c}\text { Cohort C } \\
(n=23)\end{array}$ & p-value ${ }^{\star *}$ \\
\hline Hemoglobin, g/dL & $13-17$ & $14(13.2-14.9)$ & $13.3(11.9-14.7)$ & 0.003 & $14.3(13.3-15.4)$ & n.s. \\
\hline $\begin{array}{l}\text { White blood cell } \\
\text { count, } \times 10^{9} \text { per } \mathrm{L}\end{array}$ & $4-10$ & $5.8(4.6-7.3)$ & $6.4(4.6-9.0)$ & 0.033 & $5.3(3.4-7.3)$ & n.s. \\
\hline $\begin{array}{l}\text { Lymphocyte count, } \\
\times 10^{9} \text { per L }\end{array}$ & $1.0-4.8$ & $1.5(1.1-1.9)$ & $0.8(0.6-1.1)$ & $<0.001$ & $1.0(0.7-1.4)$ & $<0.001$ \\
\hline $\mathrm{CRP}, \mathrm{mg} / \mathrm{L}$ & $<5$ & $13.2(2.0-40.8)$ & $89.3(37.6-148.1)$ & $<0.001$ & $46.4(21.8-106.8)$ & $<0.001$ \\
\hline Pprocalcitonin, $\mathrm{ng} / \mathrm{mL}$ & $<0.05$ & $0.05(0.05-0.06)$ & $0.10(0.06-0.30)$ & $<0.001$ & $0.06(0.05-0.11)$ & $<0.001$ \\
\hline Interleukin-6, pg/mL & $<15$ & n.a & $43.1(15.8-83.8)$ & & n.a. & \\
\hline Ferritin, $\mu \mathrm{g} / \mathrm{L}$ & $30-300$ & 227 (83-569) & 777 (341-1339) & $<0.001$ & $741(404-935)$ & $<0.001$ \\
\hline Iron, $\mu \mathrm{mol} / \mathrm{L}$ & $14-32$ & $8.6(5.0-14.9)$ & $2.6(1.8-3.9)$ & $<0.001$ & $3.2(2.4-4.6)$ & $<0.001$ \\
\hline Transferrin, g/L & $2.0-3.6$ & $1.9(1.6-2.3)$ & $1.5(1.2-1.7)$ & $<0.001$ & $1.7(1.6-1.9)$ & 0.012 \\
\hline TfSat, \% & $16-45$ & $19(12-28)$ & $7(5-11)$ & $<0.001$ & $8(6-10)$ & $<0.001$ \\
\hline Hepcidin, ng/mL & & & $91.4(59.6-133.7)$ & & & \\
\hline $\mathrm{LDH}, \mathrm{U} / \mathrm{L}$ & $<317$ & $286(232-360)$ & $384(308-508)$ & $<0.001$ & $348(272-374)$ & 0.005 \\
\hline AST, U/L & $<37$ & n.a. & $42(32-77)$ & & n.a. & \\
\hline $\mathrm{ALT}, \mathrm{U} / \mathrm{L}$ & $<35$ & n.a. & $36(27-57)$ & & n.a. & \\
\hline Creatinine, $\mathrm{mg} / \mathrm{dL}$ & $0.6-1.2$ & $0.74(0.65-0.88)$ & $0.88(0.69-1.04)$ & $<0.001$ & $0.92(0.79-1.11)$ & $<0.001$ \\
\hline BUN, mg/dL & $<45$ & $25(20-31)$ & $28(21-44)$ & 0.001 & $29(24-34)$ & 0.005 \\
\hline NT-pro-BNP, ng/L & $<125$ & $99(54-185)$ & $247(109-849)$ & $<0.001$ & $85(46-154)$ & n.s. \\
\hline Troponin-T, pg/mL & $<14$ & n.a. & $11.5(6.0-22.3)$ & & n.a. & \\
\hline
\end{tabular}

* Comparison of p-values between cohort A and B

${ }^{* *}$ Comparison of $p$-values between cohort $A$ and $C$

Laboratory values in cohort $B$ were obtained at day of admission. Laboratory values in cohort $A$ and $C$ were obtained during outpatient visits. Cohort A and C: All available values were included in analysis. Cohort B: only values of the day of admission were included in the analysis.

\section{Abbreviations:}

LDH: lactate dehydrogenase; BUN: blood urea nitrogen; AST; alanine aminotransferase; AST: aspartate aminotransferase; CRP: C-reactive protein; PCT: procalcitonin; TfSat: transferrin saturation; n.a. = not analyzed 
medRxiv preprint doi: https://doi.org/10.1101/2020.06.26.20140525; this version posted June 26, 2020. The copyright holder for this preprint (which was not certified by peer review) is the author/funder, who has granted medRxiv a license to display the preprint in perpetuity.

All rights reserved. No reuse allowed without permission.

Table 3. Univariate and multivariable logistic regression analysis for admission status of COVID-19 patients (cohort $A+B)$

\begin{tabular}{|c|c|c|}
\hline & \multicolumn{2}{|c|}{ COVID-19 outpatient $(\mathbf{n = 2 0 4 )}$ vs inpatient $(\mathbf{n = 8 1})$} \\
\hline Covariate, effect & $\begin{array}{c}\text { Univariate analysis, } \\
\text { OR }(95 \% \mathrm{Cl}), P\end{array}$ & $\begin{array}{c}\text { Multivariate analysis, } \\
\text { aOR }(95 \% \mathrm{Cl}), P\end{array}$ \\
\hline Age, $\geq 60$ vs. $<60$ years & $2.26(1.39-3.70), 0.001$ & $0.60(0.28-1.31)$, n.s. \\
\hline gender, m vs f & $3.38(2.05-5.57),<0.001$ & $1.37(0.65-2.89)$, n.s. \\
\hline CRP, per log2 increase* & $2.14(1.78-2.59),<0.001$ & $1.20(0.87-1.66)$, n.s. \\
\hline Serum ferritin, per log2 increase* & $1.64(0.14-1.93),<0.001$ & $\mathbf{1 . 5 7}(\mathbf{1 . 1 4 - 2 . 1 4}), \mathbf{0 . 0 0 5}$ \\
\hline Serum iron, per log2 increase ${ }^{*}$ & $0.15(0.10-0.23),<0.001$ & $\mathbf{0 . 1 5}(\mathbf{0 . 0 9}-\mathbf{0 . 2 6}),<\mathbf{0 . 0 0 1}$ \\
\hline transferrin & $0.15(0.08-0.28),<0.001$ & $0.90(0.26-0.32)$, n.s. \\
\hline Transferrin saturation, per log2 increase* & $0.20(0.14-0.29),<0.001$ & \\
\hline Goodness-of- fit test & & $X^{2}=12.97(8 \mathrm{df}), P=0.11$ \\
\hline
\end{tabular}

Abbreviations: COVID-19, Coronavirus-disease 2019; OR, odds ratio; aOR, adjusted odds ratio; Cl, confidence interval; df, degrees of freedom.

*Each one unit increase in log2 corresponds to a doubling in the corresponding parameter.

‡Hosmer-Lemeshow test. 
medRxiv preprint doi: https://doi.org/10.1101/2020.06.26.20140525; this version posted June 26, 2020. The copyright holder for this preprint (which was not certified by peer review) is the author/funder, who has granted medRxiv a license to display the preprint in perpetuity.

Figure 1

A

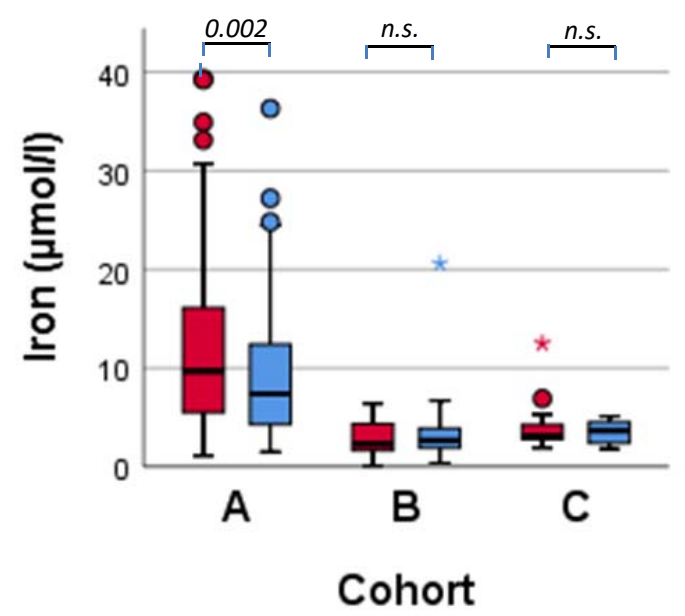

C

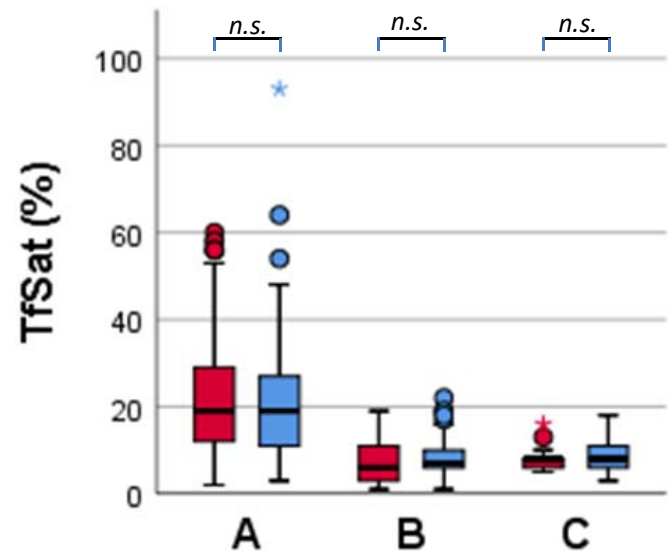

Cohort
B

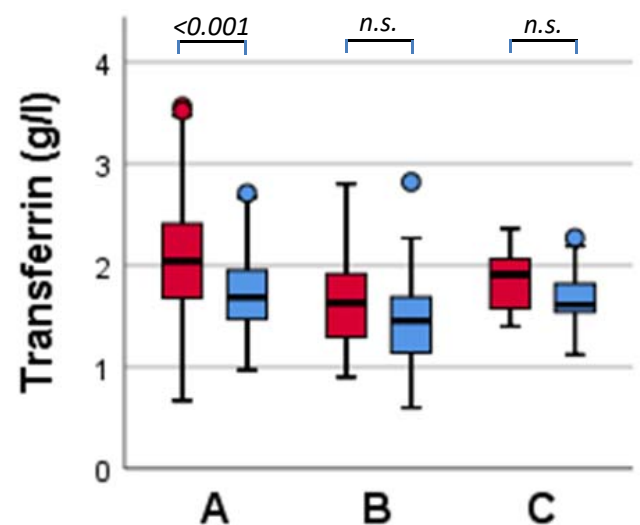

Cohort

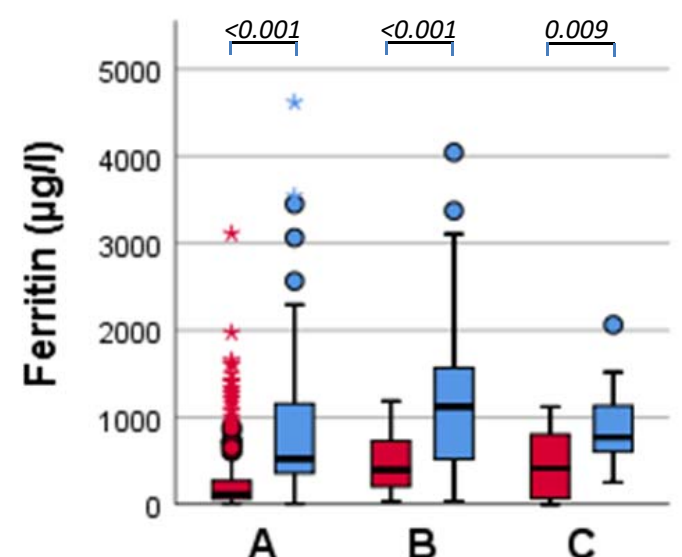

Cohort 
medRxiv preprint doi: https://doi.org/10.1101/2020.06.26.20140525; this version posted June 26, 2020. The copyright holder for this preprint (which was not certified by peer review) is the author/funder, who has granted medRxiv a license to display the preprint in perpetuity.

\section{Figure 2}

A

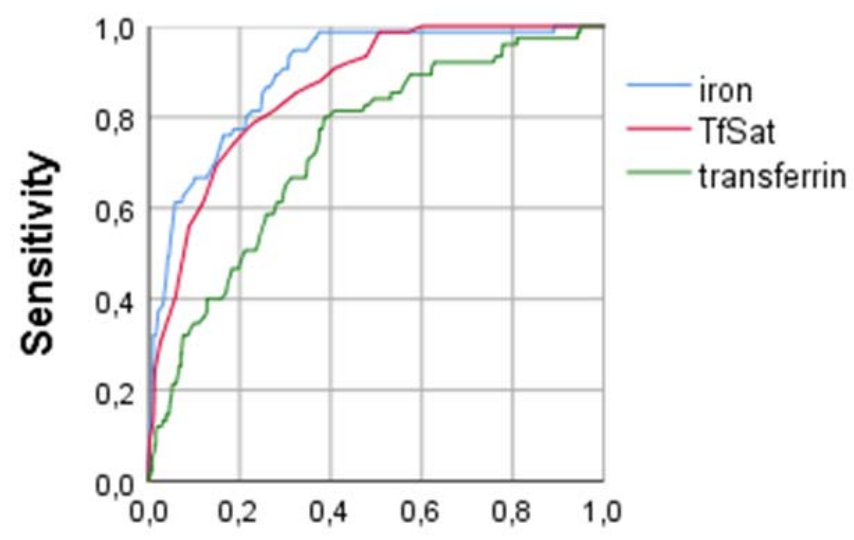

1 - Specificity

B

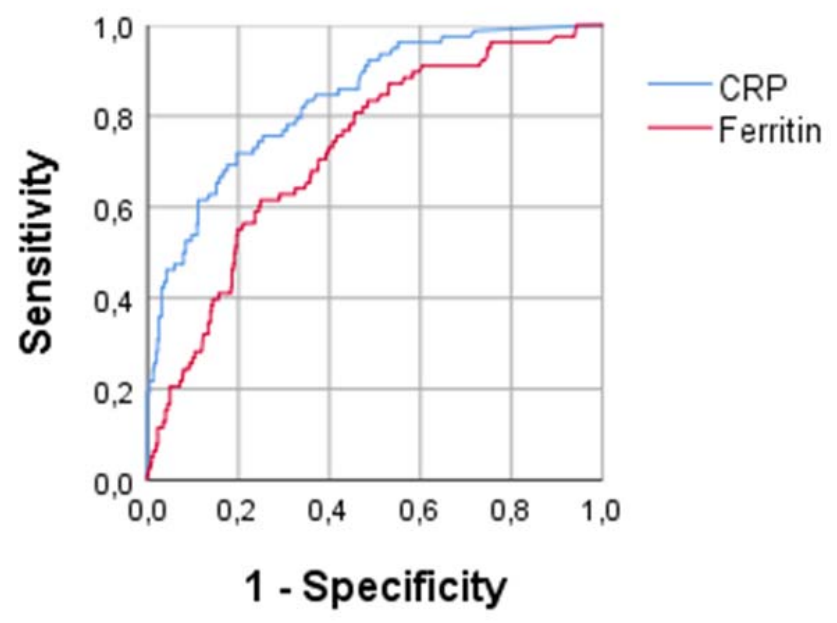

C

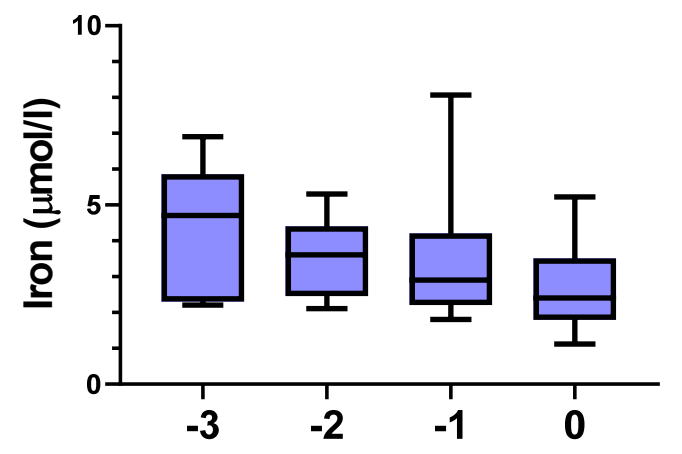

day before admission 
medRxiv reprint dol: https://doi.org/10.1101/2020.06.26.20140525; this version posted June 26, 2020. The copyright holder for this preprint (which was not certified by peer review) is the author/funder, who has granted medRxiv a license to display the preprint in perpetuity.
All rights reserved. No reuse allowed without permission.
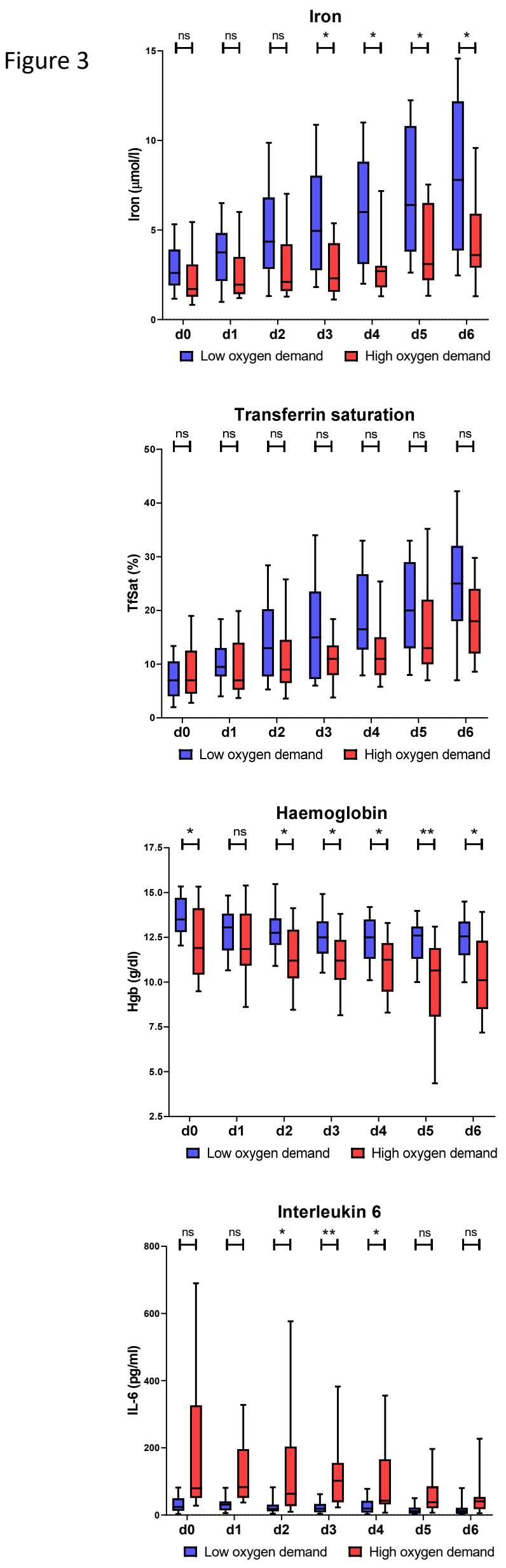
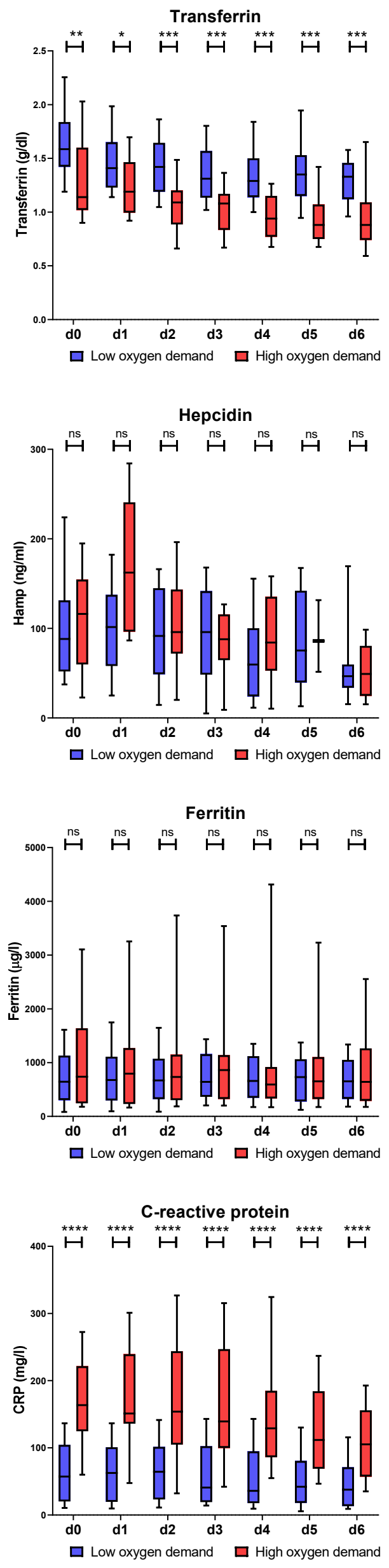

19 
medRxiv preprint doi: https://doi.org/10.1101/2020.06.26.20140525; this version posted June 26, 2020. The copyright holder for this preprint (which was not certified by peer review) is the author/funder, who has granted medRxiv a license to display the preprint in perpetuity.

Figure 4
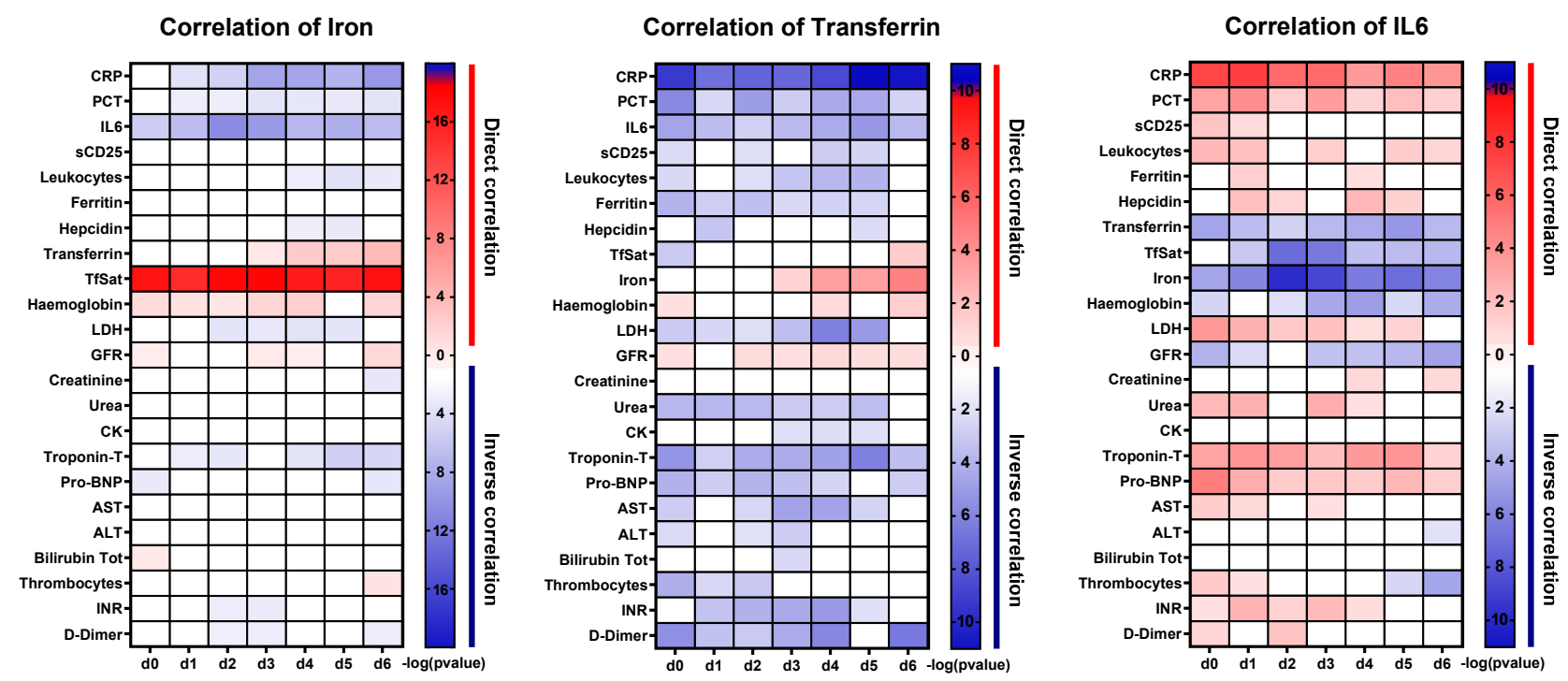
medRxiv preprint doi: https://doi.org/10.1101/2020.06.26.20140525; this version posted June 26, 2020. The copyright holder for this preprint (which was not certified by peer review) is the author/funder, who has granted medRxiv a license to display the preprint in perpetuity.

Figure 5

\section{Anakinra}
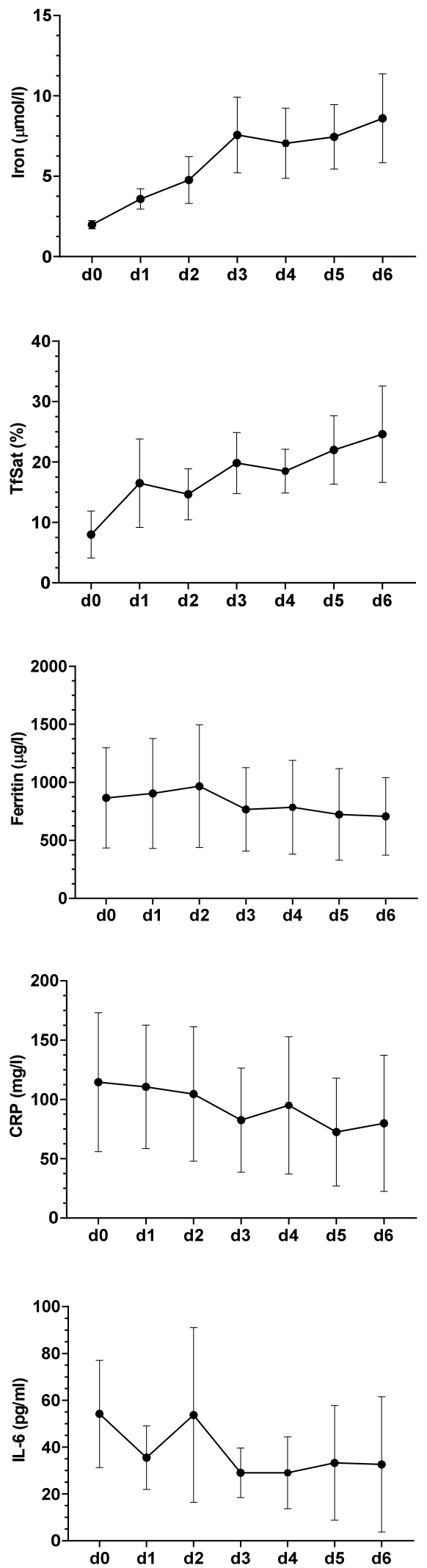

Tocilizumab
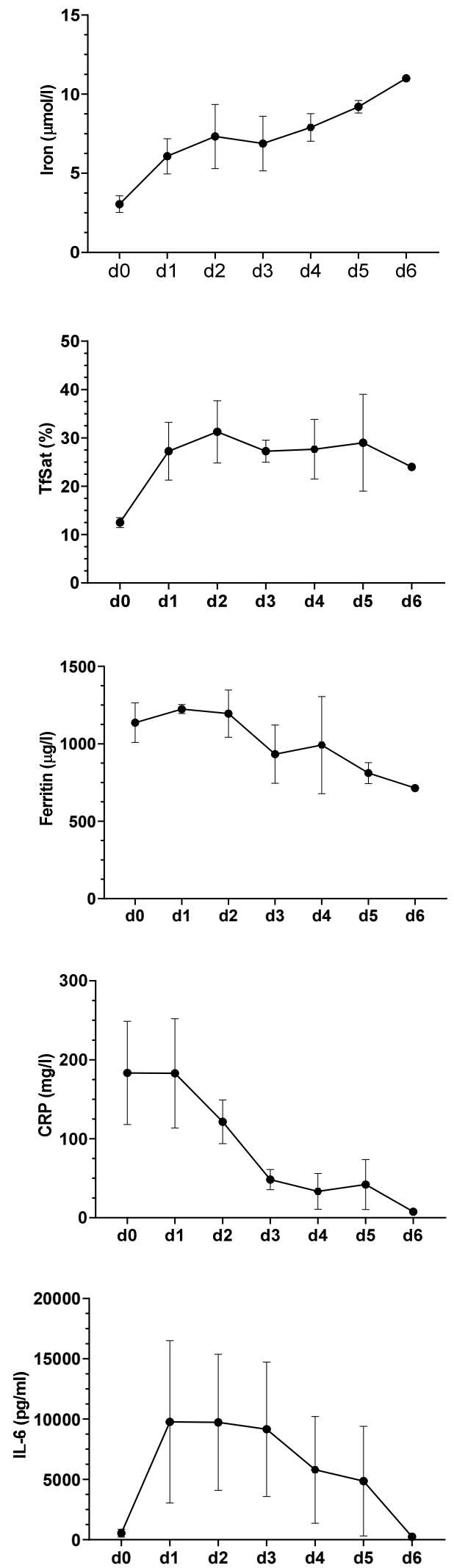

Immunoglobulines
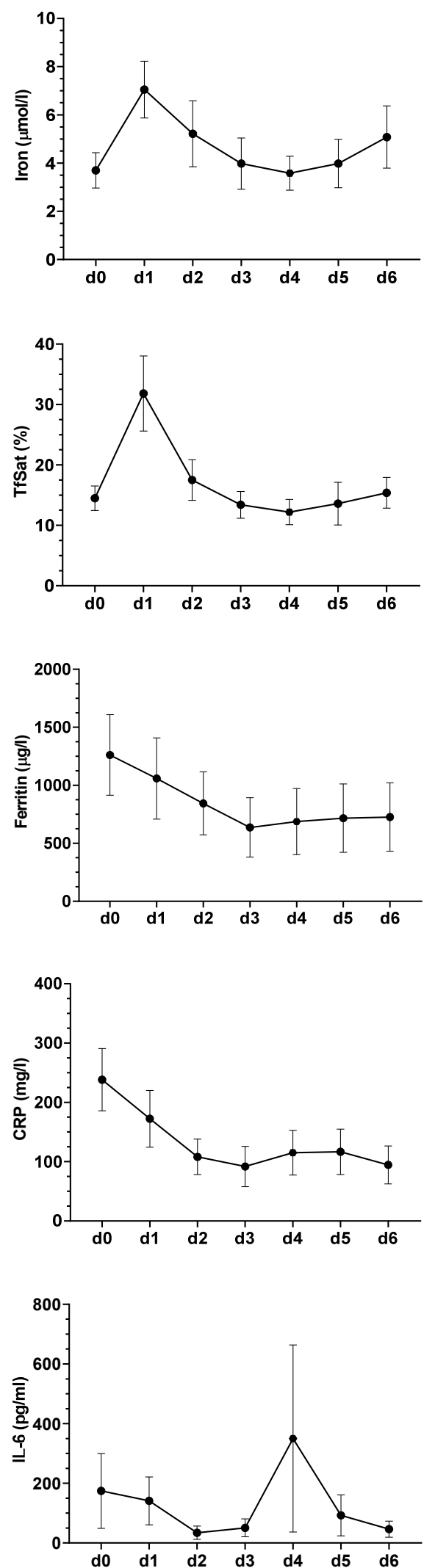